\title{
EVALUATION OF EXPERIMENTS ON A TWIN SCROLL TURBOCHARGER TURBINE FOR CALIBRATION OF A COMPLEX 1-D MODEL
}

\section{ZDENĚK ŽÁK, JAN MACEK, PETR HATSCHBACH}

Czech Technical University, Vehicle Centre of Sustainable Mobility, Technická 4, 16607 Praha 6

E-mail: zdenek.zak@fs.cvut.cz, jan.macek@fs.cvut.cz, petr.hatschbach@fs.cvut.cz

\section{ABSTRACT}

The goal of the contribution is to describe the process of measurement on a twin entry turbocharger turbine, and evaluation of obtained data. A specific feature of the twin entry turbine measurement is the separation of turbine sections. It is necessary to control different conditions in each section to achieve partial admission of the turbine impeller. The results are fundamental for the calibration process of a developed physical 1-D model of a radial turbine with twin scroll.

KEYWORDS: TWIN SCROLL TURBINE, TURBOCHARGER TEST BED, TURBOCHARGER ENERGY BALANCE, ADIABATIC COMPRESSOR, BLOCKED IMPELLER, COMPLEX I-D TURBINE MODEL

\section{SHRNUTI}

Cílem příspěvku je popsat proces měření a vyhodnocení získaných dat pro zjištění vlastností turbíny turbodmychadla se dvouvstupovou skříní. Specifikem měření dvouvstupových turbín je nutnost oddělení sekcí. Je nezbytné rídit rozdílné podmínky v sekcích pro dosažení parciálního ostřiku oběžného kola turbíny. Získané výsledky tvoří základ pro kalibraci vyvinutého fyzikálního 1-D modelu radiální turbíny se dvouvstupovou skříní.

KLÍČOVÁ SLOVA: DVOUVSTUPOVÁ TURBÍNA, TESTOVACI STAV TURBODMYCHADEL, ENERGETICKÁ BILANCE TURBODMYCHADLA, ADIABATICKÝ KOMPRESOR, ZASTAVENÉ OBĚŽNÉ KOLO TURBÍNY, KOMPLEXNÍ 1-D MODEL TURBÍNY

\section{INTRODUCTION}

The twin scroll design of radial centripetal turbines is suitable for combustion engines with a pulsation exhaust system. The low volume exhaust systems with pulsating flow are typical for highly boosted downsized internal combustion engines. The advantage of an engine equipped with a twin entry turbine is primarily in the better response during the load or speed transients.

The goal of the research is to describe the turbine behaviour under on-engine conditions, i.e. under unsteady flow and unequal partial admission of the turbine wheel. The research has to begin on the steady flow turbocharger test bed. The contribution presents the specific turbocharger hot gas stand with separated turbine sections, the evaluation methods of the measured results and the mapless approach, which is capable to describe the twin entry turbine performance under an arbitrary level of an impeller admission without the standard steady flow maps.

For the measurement of twin scroll turbocharger turbine under different admission levels, it was needful to develop a specific turbocharger test bed with separated turbine sections. The test bench was developed and properly tested in cooperation with the company ČZ a.s., Turbo division. The developed test bed significantly extends the potential of the current test facility and also adds new features to the test bed. At the early stage of the development, it was useful to create the virtual model of the future test bench for twin scroll turbochargers in GT-SUITE. The main dimensions of the test bed, boundary conditions, diameters of measuring orifices and throttling orifices are based on simulation results of the virtual open loop test bed. The proper combination of turbine selected for experiments, different systems for loading it by a compressor, using, e.g., a larger compressor wheel, detailed specification and schedule of real experimental work were also assessed in GT-SUITE.

It is possible to measure the whole family of the twin entry turbines produced by ČZ a.s. on the developed test bed. It allows turbine testing at different pressures and temperatures turbine upstream. It is possible to test a turbine under uniform admission (mass flow rates in sections are equal), different level of partial admission (via throttling in one turbine section) and in the extreme case with one section closed. The turbocharger turbine can be driven by air, hot gases or a mixture of the two for better temperature control. The fuel is natural gas. The mass flow rate via the test facility is limited to $0.5 \mathrm{~kg} / \mathrm{s}$ and the maximum temperature at burner outlet can be $1000^{\circ} \mathrm{C}$. 
The performing of measurements on the twin scroll turbocharger turbine over a wide range of temperatures, RPM, mass flow rates, different levels of impeller admission and load is essential for further development of turbocharger models based on physics. The partial admission of a turbine wheel and pulsating operation are typical for the twin entry turbocharger turbine. The optimal firing interval between cylinders to increase the advantages of turbine pulsating flow is about 120 degrees, so the twin scroll turbine is suitable for six cylinder engines. The chosen 1-D simulation approach is suited to the preliminary development of the turbocharged internal combustion engine. Due to description of the phenomena inside the turbocharger, the developed full 1-D unsteady turbine model is able to support the development of the detailed 3-D CFD model of a turbine.

\section{EXPERIMENTS}

The turbocharger test bed designated for testing twin entry turbines allows measurement of mass flow rates (orifice measuring sections $A, B$, including backflow if it occurs), temperatures and static pressures located upstream (sections $A, B$ ) and downstream of the turbine, midstream pressure at turbine outlet (without the influence of tangential velocity component), turbocharger speed, pressures, temperatures and volume flow rate of oil, mass flow rate via compressor, temperatures and pressures compressor upstream/ downstream. See Figure 1 and Figure 2.

The mentioned test facility enables measurement of the twin scroll turbocharger turbine performance under uniform admission (like a single scroll machine), partial admission of turbine wheel via throttling in one section and partial admission with closed section. It is also possible to measure back flow if it occurs, see Figure 3.

The important feature of the open loop test bed is the ability to test a turbine over a wide range of blade speed ratio (BSR). When the turbine is driven by cold air only, the turbine is unloaded and BSR increases. It is more difficult to overload the turbine, thus decrease the blade speed ratio. In all analyzed cases, a complicated lay-out with a turbine dynamometer has been excluded. The first method is to increase the temperature upstream of a turbine, the second is to load the turbine using a larger compressor wheel, and the third is the combination of both methods. The other option, increasing pressure at compressor inlet and closing the air loop in the compressor circuit, was not used due to complicated lay-out and high thrust force at turbocharger shaft. No method analyzed excludes side-effects, such as change of turbine Reynolds number (blade and windage losses) or friction losses due to thrust bearing. The final decision was a combination of the current turbine wheel with a larger compressor wheel and an increase in the turbine upstream temperature to $800^{\circ} \mathrm{C}$ for the purposes of the current measurements. The standard temperature during turbocharger testing is around $600^{\circ} \mathrm{C}$ upstream of a turbine. The selected radial turbine with twin entry volute was measured under full and partial admission of an impeller, at different blade speed ratios and different pressure ratios. Using a compressor as

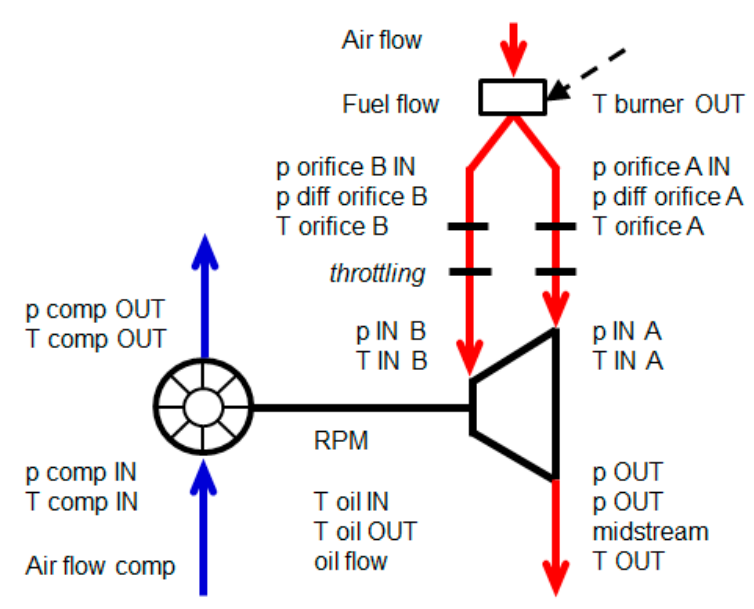

FIGURE 1: Measurement chain of the developed turbocharger test bed with open loop

OBRÁZEK 1: Měřicí řetězec vyvinutého testovacího stavu s otevřenou smyčkou

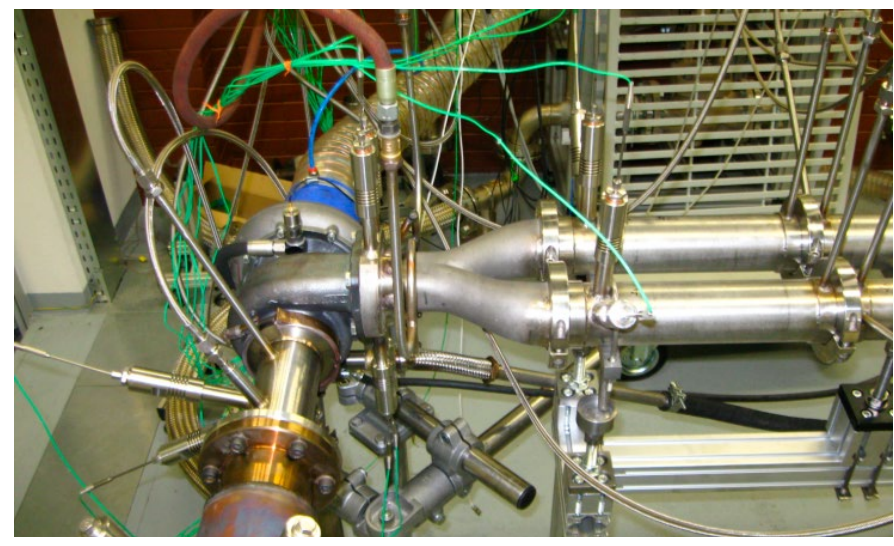

FIGURE 2: Turbocharger test bed with separated sections of the turbine with twin entry volute

OBRÁZEK 2: Testovací stav s oddělenými sekcemi dvouvstupové turbíny
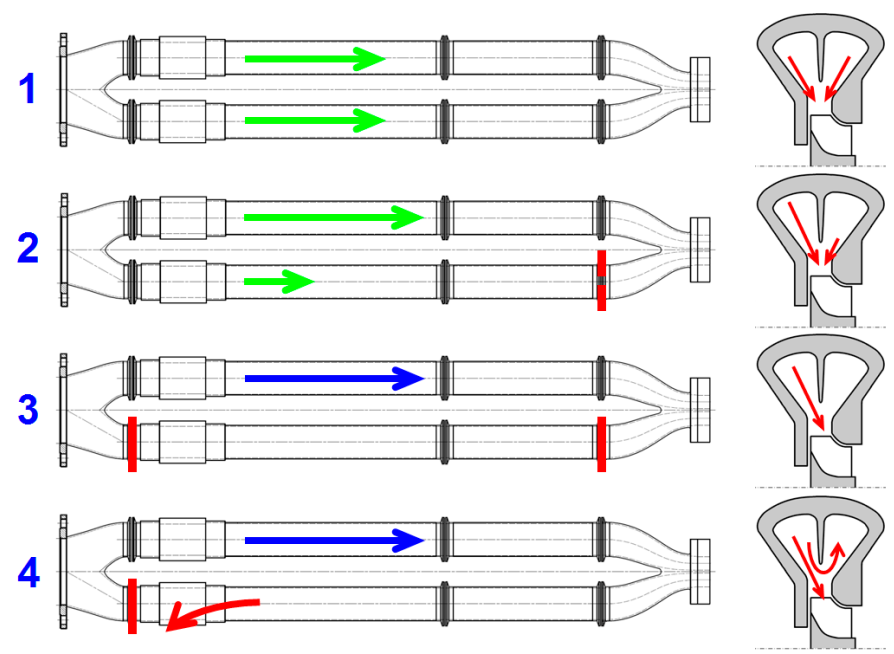

FIGURE 3: Test bed capability and types of measurement: 1) uniform admission; 2) partial admission (throttling in one section); 3) closed section; 4) backflow

OBRÁZEK 3: Možnosti testovacího stavu a typy zkoušek: 1) stejnoměrný ostřik oběžného kola turbíny; 2) parciální ostřik (škrcení v jedné sekci);

3) jedna zavřená sekce; 4) zpětný tok 
the loading machine, the compressor input power has to be measured accurately excluding the well-known influence of heat fluxes inside turbocharger casings (Figure 4). For that purpose, the turbocharger energy balance has to be analyzed.

\section{ENERGY BALANCE OF A TURBOCHARGER WITH TWIN ENTRY TURBINE}

The evaluation of turbine measurement with hot gas, which enables achievement of optimum blade speed ratio, is associated with some problems due to heat transfer inside the turbocharger components - Figure 4. A turbine does not work under adiabatic conditions. Therefore, the indirect evaluation of internal turbine power from the difference of inlet and outlet enthalpy is not accurate enough. Moreover, the heat flux between turbine and compressor casings increases the compressor outlet temperature and also distorts the relation between compressor specific power and the enthalpy difference determined from these temperatures. Assuming that the heat flux via turbocharger shaft and casings to a compressor impeller is negligible, the compressor power is independent of turbine temperatures, since the work transferring part performs almost adiabatically. To avoid heat transfer to the compressor stator, which would distort the determination of the enthalpy difference, turbine feeding by cold air was used for calibration of compressor power based on enthalpy difference. This operation mode was used for calibration of friction losses measured from oil enthalpy difference. During turbine hot tests, the compressor power was calculated from the calibrated dependence of compressor mass flow rate and speed, as explained below.

The friction losses at the bearings can be determined during cold tests although it is not possible to obtain the bearings power losses directly from oil temperature difference, because the outlet oil temperature is increased by the heat flux via turbocharger shaft (1).

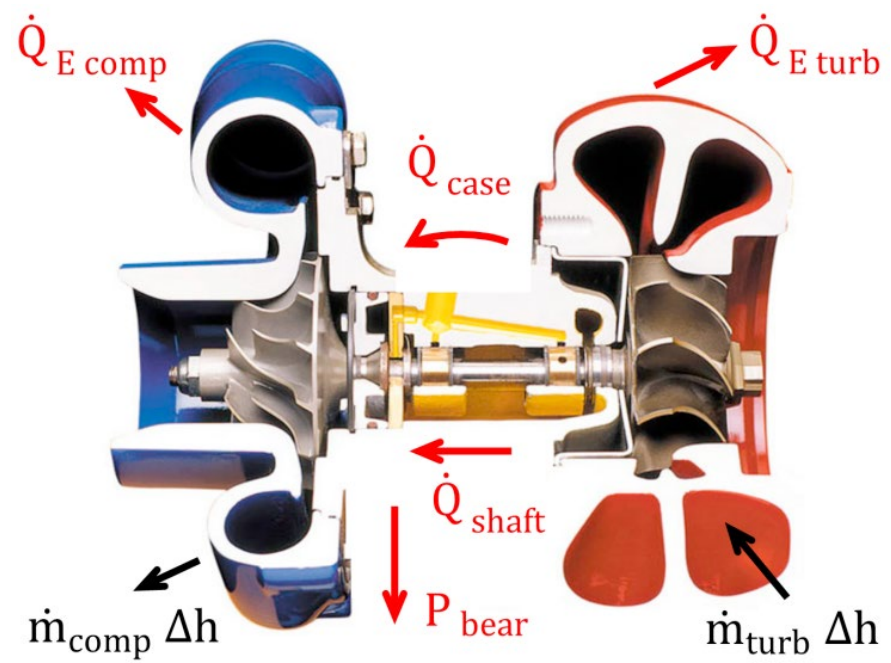

FIGURE 4: Energy balance of a turbocharger with relevant energy fluxes OBRÁZEK 4: Energetická bilance turbodmychadla s relevantními energetickými toky $\dot{m}_{\text {oil }}\left(h_{\text {OUT_oil }}-h_{\text {IN_oil }}\right)=P_{\text {bear }}+\dot{Q}_{\text {shaft }}$

The results are only correct when the heat transfer from the turbine side is insignificant, e.g. in the case of a turbine driven by cold air (the mean temperature of oil roughly equals the mean gas temperature at a turbine). The solution consists of the use of a specific regression formula, which is capable to determine the pure bearing losses ( $P$ bear) and the heat flux via shaft ( $Q$ shaft) from the turbocharger speed, mean gas temperature at the turbine, mean oil temperature, and compressor and turbine inlet/outlet pressures [11]. The regression formula for the calculation of pure losses in bearings is stated in (2).

$$
\begin{aligned}
& P_{\text {bear }}=A_{0}+A_{1} T_{\text {ave_oil_IN } ; \text { oUT }}+A_{2} T_{\text {ave_oil_IN } ; \text { oUT }}^{2}+ \\
& +A_{3} R P M+A_{4} R P M^{2}+A_{5} R P M^{3}+A_{6} p_{I N \_A B}+ \\
& +A_{7} p_{\text {OUT }}+A_{8} p_{\text {comp_IN }}+A_{9} p_{\text {comp_ouT }}
\end{aligned}
$$

If the compressor map is measured with a turbine driven by hot gases as usual, the heat fluxes from the turbine side influence the state downstream of the compressor and the compressor efficiency is then underestimated. The turbine power has to be evaluated from the whole turbocharger energy balance. During the experimental work, it was necessary to measure both compressors under different conditions.

Since the heat flux through a shaft to a compressor and external heat flux from a compressor impeller are small at any turbine power, it is convenient to measure the compressor specific power input (i.e., enthalpy difference) when the turbine is driven by cold air only. The heat fluxes ( $Q$ case, $Q$ shaft) from turbine to compressor housing are almost zero in the mentioned case, so the compressor is an almost adiabatic machine, Figure 4.

The enthalpy difference depends on compressor speed and mass flow rate only. It can be calculated from these parameters even for hot gas operation if the changes in shaft and compressor wheel heat fluxes are negligible. The compressor power may be represented by a regression formula based on Euler's theorem (3).

$$
\begin{aligned}
& P_{\text {comp_adi }}=\dot{m}_{\text {comp }} \cdot \\
& \cdot\left(K_{1} u_{2}^{2}+K_{2} w_{2 \_r} u_{2}+K_{3} w_{2 \_r}^{4}+K_{4} \frac{u_{2}^{4}}{w_{2 \_}^{2} r}\right)
\end{aligned}
$$

The radial velocity at compressor outlet is determined from the mass flow rate via the compressor and main dimensions of the compressor wheel (4).

$$
w_{2 \_}=\frac{\dot{m}_{\text {comp }}}{\pi D_{2} b_{2} \rho_{2}}
$$

The appropriate circumferential velocity is calculated using equation (5).

$$
u_{2}=\frac{\pi D_{2} R P M}{60}
$$


The regression coefficients in dependence on turbocharger speed, based on measurement of an almost adiabatic compressor, are used for the assessment of compressor power under any conditions.

When the power of an adiabatic compressor and the pure losses in bearings are known, the isentropic (6) and overall turbine efficiency (7) can be determined.

$\eta_{\text {turbine_ise }}=\frac{P_{\text {comp_adi }}+P_{\text {bear }}}{P_{\text {turbine_AB_ise_t_s }}}$

$\eta_{\text {turbine_overall }}=\frac{P_{\text {comp_adi }}}{P_{\text {turbine_AB_ise_t_s }}}$

The calculation of further partial energy fluxes (Figure 4) is not required for current purposes. The overall twin entry turbine parameters have to take into account the interactions between turbine sections $A$ and $B$. The procedures are based on averaging according to the power of sections $A$ and $B$, see (8).

$\left(\dot{m}_{A}+\dot{m}_{B}\right) \frac{c_{S A B}^{2}}{2}=\dot{m}_{A} \frac{c_{S A}^{2}}{2}+\dot{m}_{B} \frac{c_{S B}^{2}}{2}$

The definition of the fictitious isentropic velocity (9) is derived from the balance of isentropic powers $A$ and $B$.

$$
\begin{aligned}
& \frac{c_{S A B}^{2}}{2}=\frac{1}{\left(\dot{m}_{A}+\dot{m}_{B}\right)}\left(\dot{m}_{A} \bar{c}_{p A} T_{I N A_{-} t o t}\left[1-P R_{A}^{\frac{1-\bar{\kappa}_{A}}{\bar{\kappa}_{A}}}\right]+\right. \\
& \left.+\dot{m}_{B} \bar{c}_{p B} T_{I N B_{-} t o t}\left[1-P R_{B}^{\frac{1-\bar{\kappa}_{B}}{\bar{\kappa}_{B}}}\right]\right)
\end{aligned}
$$

The overall pressure ratio (total - static) of the twin entry turbine is calculated via the relation (10).

$P R_{A B_{-} t_{-} S}=\left[1-\frac{\dot{m}_{A} \frac{c_{S A}^{2}}{2}+\dot{m}_{B} \frac{c_{S B}^{2}}{2}}{\left(\dot{m}_{A}+\dot{m}_{B}\right) \overline{c_{p}} T_{I N A B_{-} t o t}}\right]^{\frac{\bar{\kappa}}{1-\bar{\kappa}}}$

The turbine blade speed ratio (11) is defined as a fraction of the circumferential velocity and fictitious isentropic velocity.

$B S R_{A B}=\frac{\pi D_{r e f} R P M}{60 c_{S} A B}$

The level of admission of the turbine impeller is the quotient of the isentropic power in the appropriate turbine section and the total isentropic power (12). The admission level of section B is analogical to equation (12).

$$
\text { level }_{A}=\frac{\dot{m}_{A} \frac{c_{S_{-} A}^{2}}{2}}{\dot{m}_{A} \frac{c_{S_{-} A}^{2}}{2}+\dot{m}_{B} \frac{c_{S_{-} B}^{2}}{2}}
$$

The overall discharge coefficient of the twin entry turbine (13) is evaluated as a fraction of the mass flow rates sum to the reference mass flow rate via machine.

$$
\mu_{t u r b \_A B}=\frac{\dot{m}_{A}+\dot{m}_{B}}{\dot{m}_{\text {ref }}}=\frac{\dot{m}_{A}+\dot{m}_{B}}{A_{t_{-} r e f} \frac{p_{I N A B_{-} t}}{\sqrt{r_{I N A B_{-} t T_{I N A B_{-} t}}}} \sqrt{\psi_{A B}}}
$$

\section{EVALUATION OF MEASURED DATA}

The developed regression formula (2) represents the experimental data very well - Figure 5, almost avoiding the dependence of friction losses on turbine averaged temperature. The low power losses in bearings are caused by low load of bearings and the measurement during turbocharger warm-up in several cases. The results of the regression are the power losses in bearings. The heat flux via turbocharger shaft has to be evaluated from equation (1). The comparison of measured compressor power under different conditions is in Figure 6. The measured compressor power, when the turbine is driven by exhaust gases, is influenced by the heat transfer from the turbine side. The impact of the heat transfer from turbine to compressor housing is significant especially at low turbocharger speed, where the compressor efficiency is underestimated considerably. The effect decreases with increasing compressor speed, Figure 7. The measured compressor efficiency is almost equal to the result of the appropriate regression formula at high speeds.

Coefficients $\mathrm{K} 1-\mathrm{K} 4$, used in the regression formula (3) for the calculation of the compressor power, in dependence on compressor speed are presented in Figure 8.

The efficiency of the compressor measured when the turbine is driven by exhaust gases compared to the results of the regression formula based on the Euler's theorem is shown in Figure 9. The impact of the heat transfer from the turbine side is clearly visible.

Turbine efficiency in dependence on pressure ratio, mass flow rate and full or partial admission of an impeller is influenced by the turbine scroll dimensions, the turbine wheel and the interaction of flows impeller upstream, Figure 10. The optima of isentropic efficiency

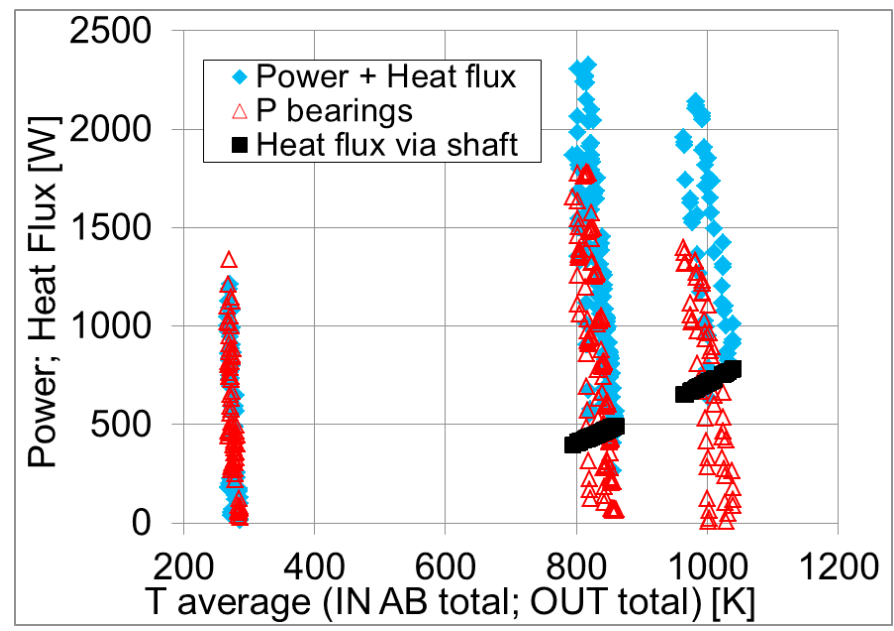

FIGURE 5: Evaluated power losses in bearings and heat flux via turbocharger shaft vs. averaged total temperature (average of total temperatures at turbine inlet sections A, B and turbine outlet); Power losses in bearings + Heat flux via turbocharger shaft (blue); Power losses in bearings only (red triangles); Heat flux via turbocharger shaft (black)

OBRÁZEK 5: Vyhodnocené ztráty v ložiskách a tepelný tok hřídelí turbodmychadla v závislosti na průměrované celkové teplotě (průměr celkových teplot na vstupu do sekcí A, B a výstupu turbíny); Ztráty v ložiskách + Tepelný tok hř́delí turbodmychadla (modrá); Samotné ztráty v ložiskách (červené trojúhelníky); Tepelný tok hřídelí turbodmychadla (černá) 


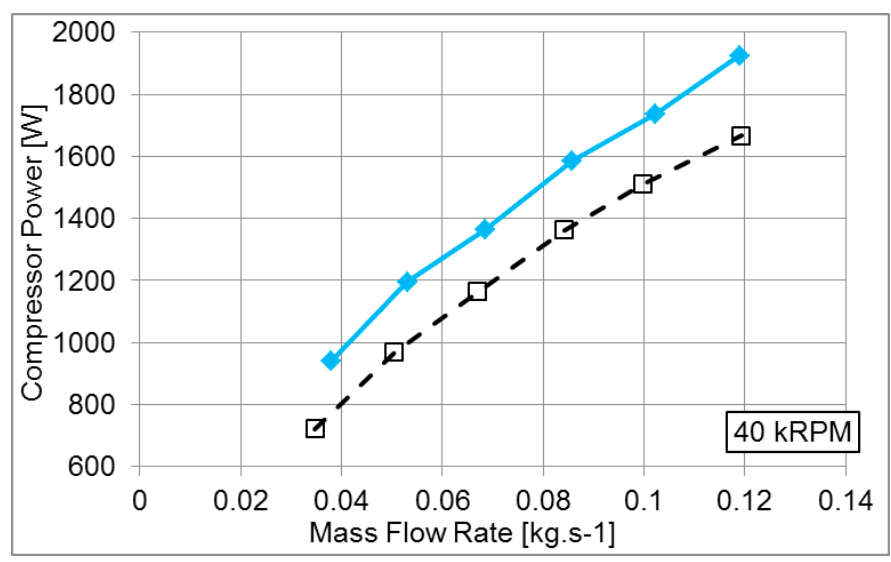

FIGURE 6: Measured compressor power (standard compressor wheel); turbine driven by exhaust gases (blue); turbine driven by cold air (black dashed line); turbocharger speed 40 kRPM

OBRÁZEK 6: Měřený výkon kompresoru (standardní kompresorové kolo); turbína hnaná výfukovými plyny (modrá); turbína hnaná studeným vzduchem (černá čárkovaná čára); otáčky turbodmychadla 40 kRPM

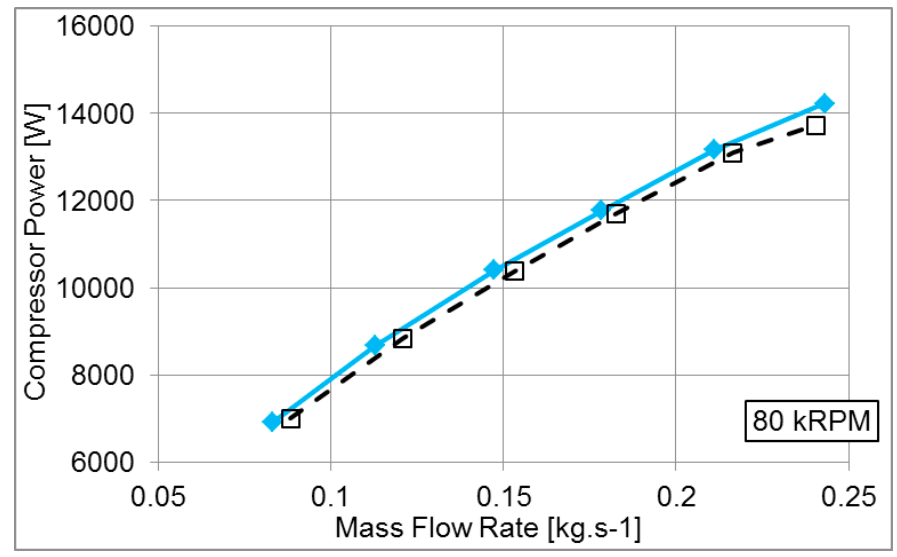

FIGURE 7: Measured compressor power (standard compressor wheel); turbine driven by exhaust gases (blue); turbine driven by cold air (black dashed line); turbocharger speed 80 kRPM

OBRÁZEK 7: Měřený výkon kompresoru (standardní kompresorové kolo); turbína hnaná výfukovými plyny (modrá); turbína hnaná studeným vzduchem (černá čárkovaná čára); otáčky turbodmychadla 80 kRPM

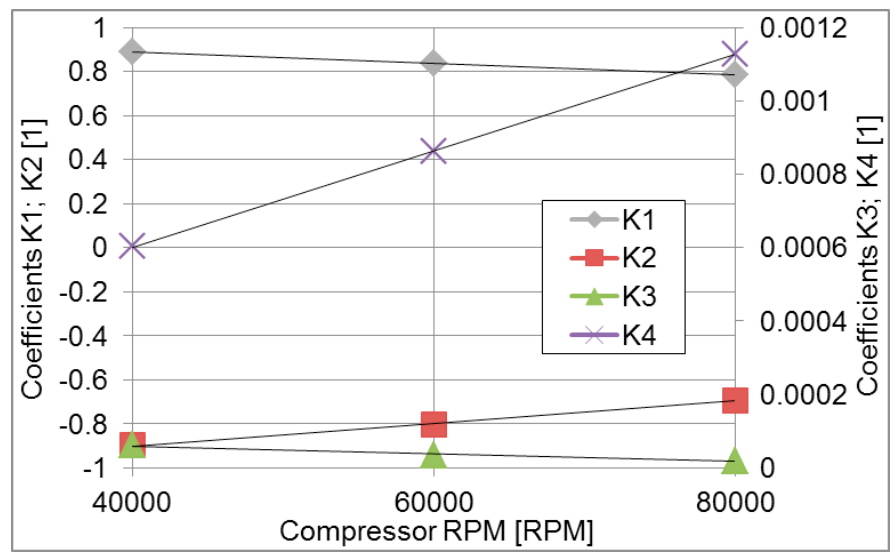

FIGURE 8: Courses of regression coefficients K1 - K4 used in the formula for calculation of compressor power (standard compressor wheel) OBRÁZEK 8: Průběhy regresních koeficientů K1 - K4 použité ve vztahu pro výpočet výkonu kompresoru (standardní kompresorové kolo)

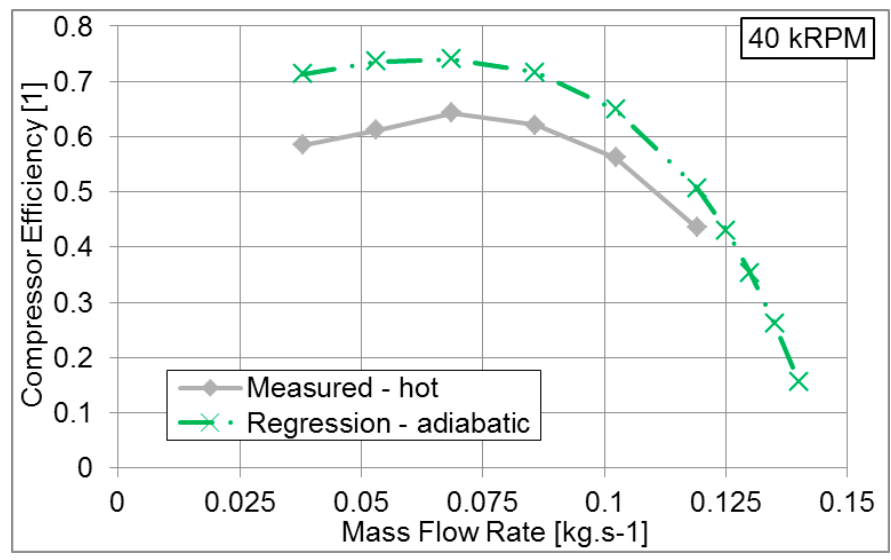

FIGURE 9: Comparison of measured compressor efficiency (turbine driven by exhaust gases) and efficiency of an adiabatic machine based on regression formula; standard compressor wheel; turbocharger speed 40 kRPM

OBRÁZEK 9: Porovnání měřené účinnosti kompresoru (turbína hnána výfukovými plyny) a účinnost adiabatického stroje dle regresního vztahu; standardní kompresorové kolo; otáčky turbodmychadla 40 kRPM

under full and partial admission of an impeller are surprisingly almost the same, but they are reached at different mass flow rates via the turbine. The maximum efficiency of a turbine with one completely closed section is lower and shifted to higher mass flow rates, see Figure 10. When comparing isentropic efficiency in dependence on blade speed ratio - BSR (11) at the same pressure ratio, the isentropic turbine power increases faster, due to increasing mass flow rate via the turbine, than the compressor power. Power losses in bearings are not so significant, so the isentropic efficiency of the turbine decreases (6), Figure 10, Figure 11 and Figure 13. The influence of the mass flow rate via the turbine is dominant.

The experimental results at low pressure ratio are in Figure 11. The turbine efficiency is affected by the partial admission of the turbine wheel (throttling in one section), which causes turbine efficiency reduction. Further decrease in the efficiency takes place in the extreme case, when one section of a turbine is closed. The evaluated discharge coefficient (13) of a turbine at almost constant pressure ratio decreases in cases of throttling in section and closed section, Figure 12.

The isentropic efficiency of a turbine under full and partial admission is almost equal at a pressure ratio of 2.2 in Figure 13. Efficiency under partial admission at high blade speed ratios is even higher than in the case of full admission. The trend is obvious from Figure 10 - the trend of efficiency courses in dependence on mass flow rate via turbine under different conditions in sections. The reason was found earlier using simulations [12]. The turbine efficiency depends on fitting the impeller and nozzle sections geometry. If the impeller exducer part is overloaded at high pressure ratios by expanded gas of high mass flow rate and low density, it increases outlet kinetic energy loss. In such a case, partial admission may help at the same mean pressure ratio since the mass flow rate is reduced in the highly loaded part by reaching the sonic limit. The impact of momentum loss at the twin scroll exit may be fully compensated by better efficiency of 

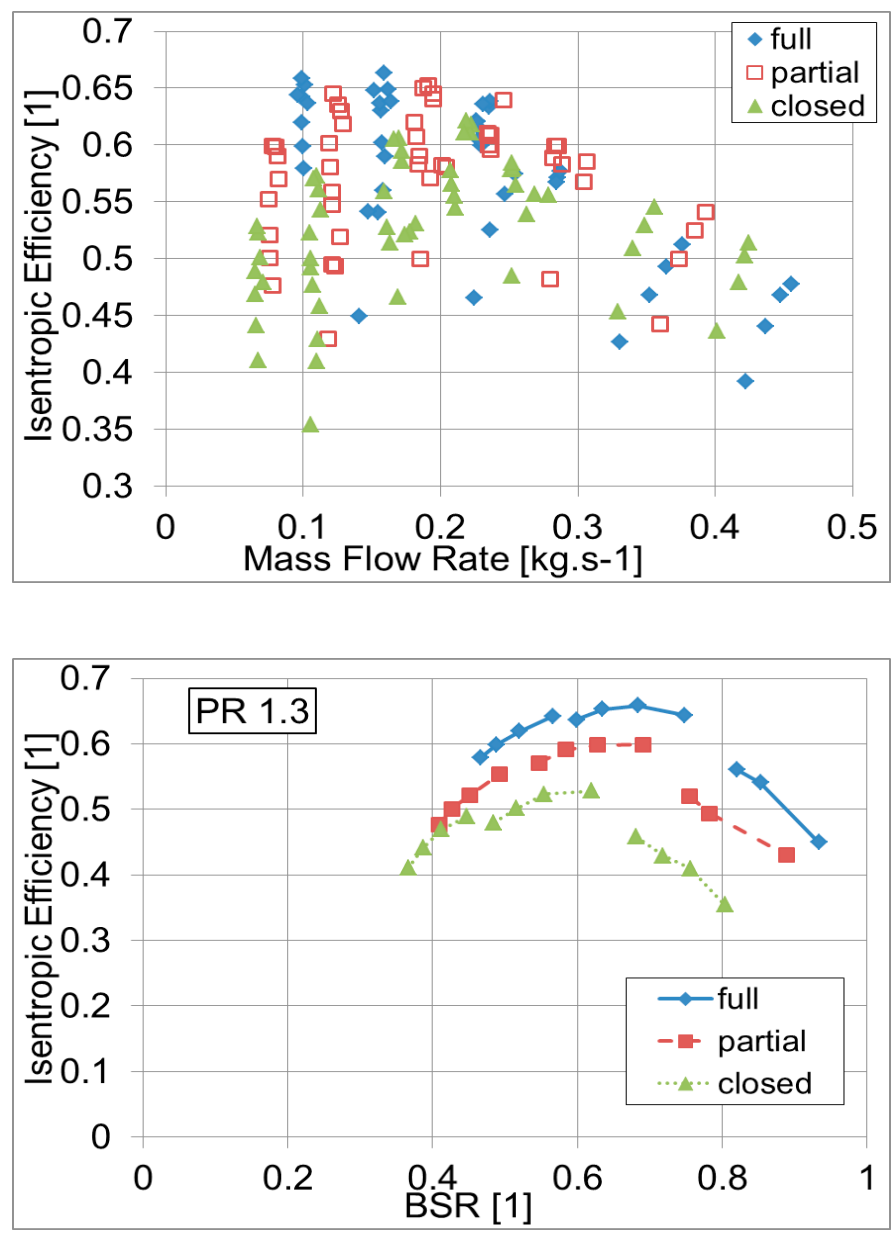

FIGURE 11: Comparison of turbine isentropic efficiency courses - overall turbine $P R A B=1.3$; full admission of an impeller (blue); partial admission (red square) - level $A=0.87$; closed section (green triangle) OBRÁZEK 11: Srovnání průběhů izoentropické účinnosti turbíny při PR $A B=1.3$; plný ostřik oběžného kola (modrá); parciální ostřik (červený čtverec) - level $A=0.87$; zavřená sekce (zelený trojúhelník)

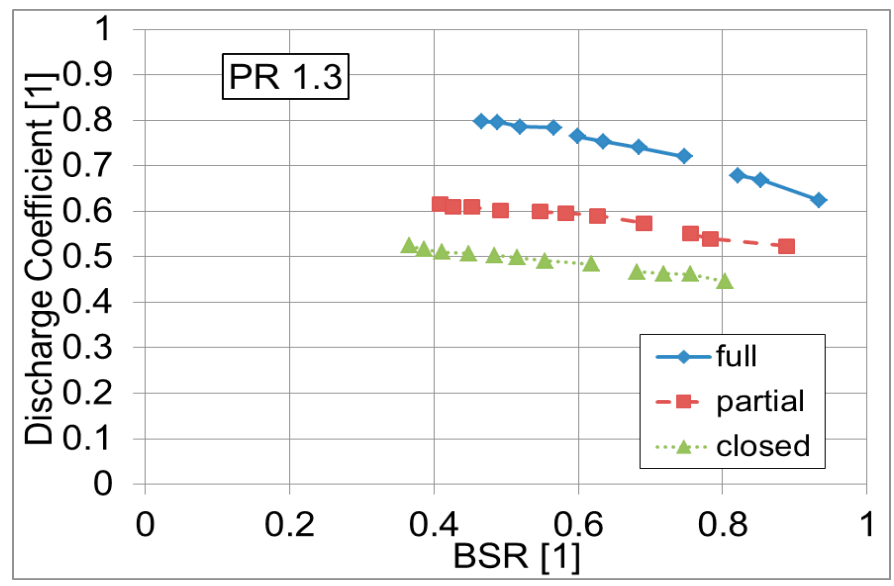

FIGURE 12: Discharge coefficient of a turbine - overall turbine PR $A B=1.3$; full admission of an impeller (blue); partial admission (red square) - level $A=0.87$; closed section (green triangle) OBRÁZEK 12: Hltnostní součinitel turbíny - PR $A B=1.3$; plný ostřik oběžného kola (modrá); parciální ostřik (červený čtverec) - level $A=0.87$; zavřená sekce (zelený trojúhelník)
FIGURE 10: Isentropic efficiency of turbine under full admission of a turbine wheel (blue); partial admission - throttling in one section (red square) - level $\mathrm{A}=0.87$; closed section (green triangle)

OBRÁZEK 10: Izoentropická účinnost turbíny při plném ostřiku oběžného kola (modrá); parciální ostřik - škrcení v jedné sekci (červený čtverec) level $\mathrm{A}=0.87$; jedna zavřená sekce (zelený trojúhelník)

the exducer, which was the investigated case. Therefore, the results presented in Figure 10, Figure 11 and Figure 13 are consistent. The zero operating point with blocked turbine impeller $(B S R=0)$ for the effect of centrifugal force assessment is also shown in Figure 13 and Figure 14. The zero point is also useful during the development and testing of regression as described in the text below.

After the evaluation of all measured data, it was necessary to prepare and adapt regression formulas for turbine isentropic efficiency and discharge coefficient over a wide range of blade speed ratios. The results of regressions are fundamental for the calibration process of a physical unsteady 1-D model of a twin scroll turbine. Measurement smoothing by regression can be used with confidence inside the measured hypercube. Regression formulas derived from [11] are properly fitted to the experimental data. The regression model is based on pressure ratio and blade speed ratio polynomials up to the third power and mixed interaction terms of both independent variables with products up to the second power. The comparison of turbine isentropic efficiency evaluated from experiments with the results of tailored regression is in Figure 15. The presented example at constant pressure ratio and full admission shows that the obtained results are satisfactory. It was necessary to prepare different formulas for full admission and two different cases of partial admission (throttling in section and closed section). The relations for efficiency and discharge coefficient are also different, so six specific regression forms are prepared in total. The tailored regression forms for efficiency or discharge coefficient as a function of turbine pressure ratio and blade speed ratio are the basis for the calibration process of the 1-D turbine model.

The discharge coefficients obtained from experiments are compared with the results of tailored regression in Figure 16 (the same measured points as in Figure 15). Knowledge of the zero point, when the turbine wheel is blocked, is useful during the regression adaptation. Extrapolation of measured data by regression is generally risky, although in the current case the results seem to be reasonable. Zero efficiency at nonzero BSR or zero discharge coefficient point have to be checked using the physical model. Before the full 1-D model is tested, the validity of extrapolation cannot be assessed. The detailed measurement, comprehensive data evaluation based on turbocharger energy balance and further data processing using the tailored specific regression formulas enable the development of the specific unsteady turbine 1-D model with calibration coefficients based on physics.

\section{CONCLUSION}

The specific turbocharger test bench for twin entry turbines was developed and properly tested during the project including the 


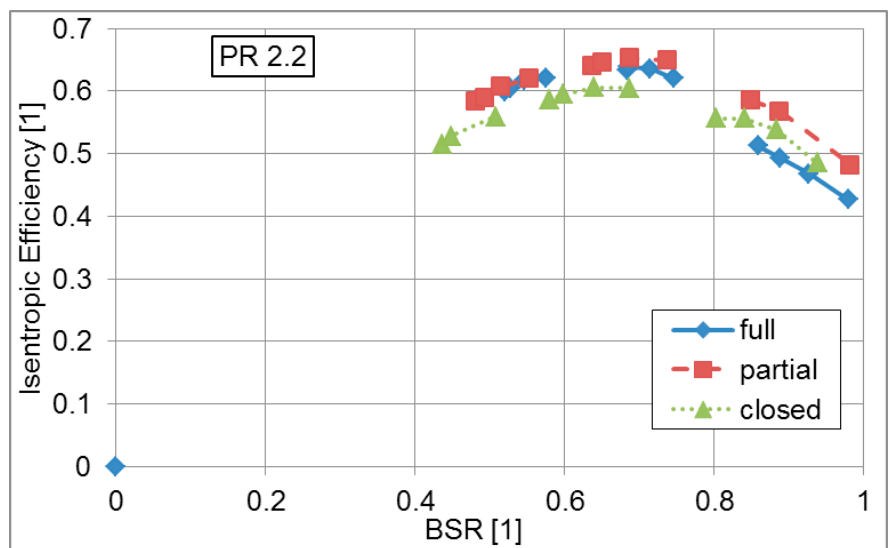

FIGURE 13: Comparison of turbine isentropic efficiency courses - overall turbine $P R A B=2.2$; full admission of an impeller (blue) (zero point blocked turbine wheel); partial admission (red square) - level $A=0.87$; closed section (green triangle)

OBRÁZEK 13: Srovnání průběhů izoentropické účinnosti turbíny při PR $A B=2.2 ;$ plný ostřik oběžného kola (modrá) (nulový bod - zastavený rotor turbíny); parciální ostřik (červený čtverec) - level $A=0.87$; zavřená sekce (zelený trojúhelník)

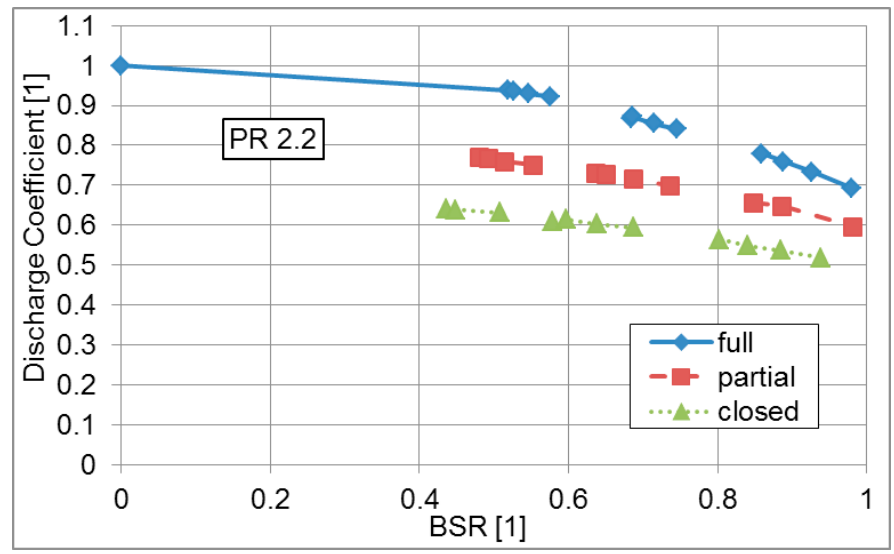

FIGURE 14: Discharge coefficient of a turbine - overall turbine PR $A B=$ 2.2; full admission of an impeller (blue) (zero point - blocked turbine wheel); partial admission (red square) - level $\mathrm{A}=0.87$; closed section (green triangle)

OBRÁZEK 14: HItnostní součinitel turbíny - PR $A B=2.2$; plný ostřik oběžného kola (modrá) (nulový bod - zastavený rotor turbíny); parciální ostřik (červený čtverec) - level $\mathrm{A}=0.87$; zavřená sekce (zelený trojúhelník)

data acquisition and evaluation of in-house software. The selected turbocharger was properly tested with emphasis on the twin entry turbine performance under full and partial admission of an impeller over a wide blade speed ratio range. The detailed analysis of the turbocharger energy balance was utilized for the evaluation of measured data. The optima of turbine isentropic efficiency under full and partial admission, the courses of turbine efficiency and discharge coefficient, valid adiabatic compressor power and efficiency under any conditions and pure losses in bearings are identified and calculated. The overall regression formulas of turbine efficiency and discharge coefficient were tailored and properly

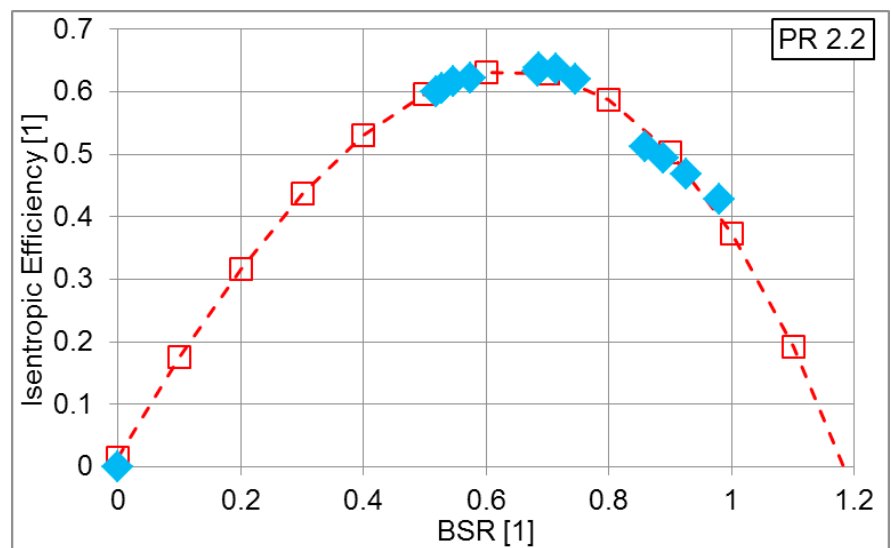

FIGURE 15: Turbine isentropic efficiency, overall turbine $P R A B=2.2$, full admission of a turbine wheel; Experimental data (blue); Results of regression (red dashed line)

OBRÁZEK 15: Izoentropická účinnost turbíny, PR $A B=2.2$, plný ostřik oběžného kola; Experimentální data (modrá); Výsledky regresí (červená čárkovaná)

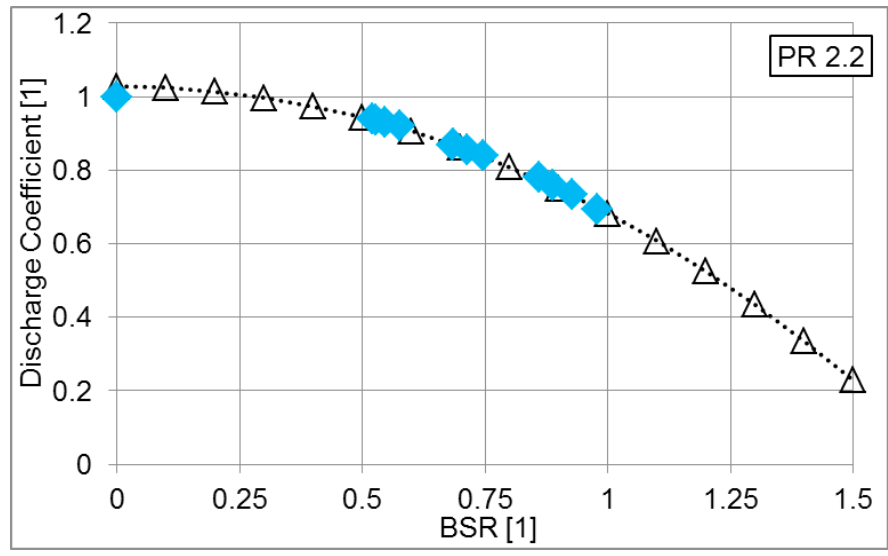

FIGURE 16: Discharge coefficient of a turbine - overall turbine PR $A B=2.2$, full admission of a turbine wheel; Experimental data (blue); Results of regression (black dotted line)

OBRÁZEK 16: Hltnostní součinitel turbíny při PR $A B=2.2$, plný ostřik oběžného kola; Experimentální data (modrá); Výsledky regresí (černá tečkovaná)

tested over a wide range of turbine loads. The obtained maps of two adiabatic compressors are the byproduct of the work. The map of the main compressor will be used during the simulation of the whole turbocharged diesel engine. The full 1-D approach extends the feasibility of modelling, not only by describing the interaction between combustion engine and turbocharger, but it also describes the phenomena inside a turbine. The physical approach respects conditions for mixing of flows inside a scroll, asymmetry of flow admission and turbine scroll design. The results obtained during the research work, briefly described in the paper, will contribute to the further development of turbocharger models and their predictive capability. The preliminary turbocharger design, i.e. main dimensions of divided symmetrical or asymmetrical scroll, turbine impeller and outlet have to be optimized using the developed unsteady 1-D 
model. The turbocharger has to be developed with the combustion engine simultaneously. The most frequent operating modes, fuel consumption and required dynamics have to be taken into account. The appropriate 3-D CFD analysis of compressor and turbine may begin after the priorities are identified with the 1-D simulation.

\section{ACKNOWLEDGEMENTS}

This work was supported by:

This research has been realized using the support of The Ministry of Education, Youth and Sports program NPU I (LO), project L01311: 'Development of Centre of Vehicles for Sustainable Mobility'.

Zvoníček's Foundation, Czech Republic, project - Development of a 1-D Model of a Radial Turbocharger Turbine Supported by the Financial Donation of Dr. Thomas Morel

All the support is gratefully acknowledged.

\section{LIST OF NOTATIONS AND ABBREVIATIONS}

\begin{tabular}{|c|c|}
\hline$A, B, A B$ & turbine sections $A, B$; overall turbine \\
\hline$A_{t_{-} \text {ref }}\left[m^{2}\right]$ & reference flow area \\
\hline$b_{2}[m]$ & compressor wheel width (outlet) \\
\hline$B S R[1]$ & blade speed ratio \\
\hline comp & compressor \\
\hline $\bar{c}_{p}\left[J k^{-1} K^{-1}\right]$ & average specific heat \\
\hline$c_{s}^{P}\left[m s^{-1}\right]$ & isentropic velocity \\
\hline$D_{2}[m]$ & compressor wheel diameter (outlet) \\
\hline$D_{r e f}[m]$ & reference diameter of turbine wheel \\
\hline$h\left[\mathrm{~J} \mathrm{~kg}^{-1}\right]$ & enthalpy \\
\hline$I N$ & inlet \\
\hline$K_{1}-K_{4}$ & regression coefficients \\
\hline level $_{A}[1]$ & admission level - turbine section $A$ \\
\hline$\dot{m}\left[k g s^{-1}\right]$ & mass flow rate \\
\hline oil & oil \\
\hline OUT & outlet \\
\hline$p[P a]$ & pressure \\
\hline$P_{\text {bear }}[W]$ & power losses in bearings \\
\hline$P_{\text {comp_adi }}[W]$ & compressor power adiabatic \\
\hline $\begin{array}{l}P_{\text {turbine_AB_ise_t_s }}[W] \\
P R[1]\end{array}$ & $\begin{array}{l}\text { isentropic turbine power total-static } \\
\text { pressure ratio total-static }\end{array}$ \\
\hline$r\left[J k^{-1} K^{-1}\right]$ & gas constant \\
\hline ref & reference \\
\hline$\dot{Q}_{\text {case }}[W]$ & heat flux between housings \\
\hline$\dot{Q}_{\text {Ecomp }}[W]$ & heat flux from compressor housing \\
\hline$\dot{Q}_{\text {Eturb }}[W]$ & heat flux from turbine scroll \\
\hline$\dot{Q}_{\text {shaft }}[W]$ & heat flux via turbocharger shaft \\
\hline$R P M[R P M]$ & turbocharger speed \\
\hline$s$ & static \\
\hline$T[K]$ & temperature \\
\hline$t$, tot & total \\
\hline$u_{2}$ & circumferential velocity \\
\hline
\end{tabular}

$w_{2 \_r}$
$\eta_{\text {turbine_sse }}[1]$
$\eta_{\text {turbine_overall }}[1]$
$\bar{\kappa}[1]$
$\mu_{\text {turb_AB }}[1]$
$\rho_{2}\left[\mathrm{~kg} \mathrm{~m}^{-3}\right]$
$\psi[1]$

radial velocity (compressor wheel outlet) isentropic turbine efficiency overall turbine efficiency average specific heat ratio discharge coefficient density at compressor outlet flow function

\section{REFERENCES}

[1] DIXON S. L.: Fluid Mechanics, Thermodynamics of Turbomachinery. Pergamon Press London 1975

[2] ZINNER, K., Supercharging of Internal Combustion Engines. Springer Heidelberg 1978

[3] WATSON, N., JANOTA, M.S., Turbocharging the Internal Combustion Engine. MacMillan Publishers, London 1982, ISBN 0333242904

[4] BRINKERT N., SUMSER S., SCHULZ A., WEBER S., FIEWEGER $\mathrm{K}$., and BAUER H.-J. Understanding the twin-scroll turbine-flow similarity. ASME Turbo Expo, 49:2207-2218, 2011.

[5] DE BELLIS, V., BOZZA, F., SCHERNUS, C., and UHLMANN, T., "Advanced Numerical and Experimental Techniques for the Extension of a Turbine Mapping," SAE Int. J. Engines 6(3):2013, doi:10.4271/2013-24-0119.

[6] FREDRIKSSON C. F., XUWEN QIU, BAINES N. C., MÜLLER M., BRINKERT N. and GUTMANN C. Meanline Modeling of Radial Inflow Turbine With Twin-Entry Scroll. ASME Turbo Expo 2012,doi:10.1115/GT2012-69018

[7] AYMANNS R.; SCHARF J.; UHLMANN T.; PISCHINGER S., Turbocharger Efficiencies in Pulsating Exhaust Gas Flow. MTZ, vol. 07-08/2012.

[8] LÜCKMANN D.; UHLMANN T.; KINDL H.; PISCHINGER S., Separation in Double Entry Turbine Housings at Boosted Gasoline Engines. MTZ, vol. 10/2013.

[9] UHLMANN T., et al. "Development and Matching of Double Entry Turbines for the Next Generation of Highly Boosted Gasoline Engines." $34^{\text {th }}$ International Vienna Motor Symposium. 2013.

[10] CAPOBIANCO, M., MARELLI, S., "Transient Performance of Automotive Turbochargers: Test Facility and Preliminary Experimental Analysis," SAE Technical Paper 2005-24-066, 2005, doi:10.4271/2005-24-066.

[11] MACEK, J., VITEK, O., and ZAK, Z., "Calibration and Results of a Radial Turbine 1-D Model with Distributed Parameters," SAE Technical Paper 2011-01-1146, 2011, doi:10.4271/2011-01-1146.

[12] MACEK, J., ZAK, Z., VITEK, 0.: "Physical Model of a Twinscroll Turbine with Unsteady Flow," SAE Technical Paper 2015-01-1718, 2015, doi:10.4271/2015-01-1718. 